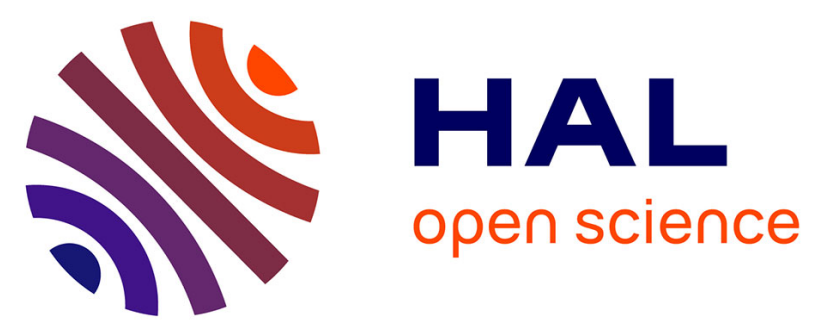

\title{
A M3 MUSCARINIC RECEPTOR COUPLED TO INOSITOL PHOSPHATE FORMATION IN THE RAT COCHLEA?
}

\author{
Janique Guiramand, Ebrahim Mayat, Sylvain Bartolami, Marc Lenoir, \\ Jean-Francois Rumigny, Rémy Pujol, Max Récasens
}

\section{To cite this version:}

Janique Guiramand, Ebrahim Mayat, Sylvain Bartolami, Marc Lenoir, Jean-Francois Rumigny, et al.. A M3 MUSCARINIC RECEPTOR COUPLED TO INOSITOL PHOSPHATE FORMATION IN THE RAT COCHLEA?. Biochemical Pharmacology, 1990, 39, pp.1913 - 1919. 10.1016/00062952(90)90609-o . hal-02163294

\section{HAL Id: hal-02163294 \\ https://hal.science/hal-02163294}

Submitted on 24 Jun 2019

HAL is a multi-disciplinary open access archive for the deposit and dissemination of scientific research documents, whether they are published or not. The documents may come from teaching and research institutions in France or abroad, or from public or private research centers.
L'archive ouverte pluridisciplinaire HAL, est destinée au dépôt et à la diffusion de documents scientifiques de niveau recherche, publiés ou non, émanant des établissements d'enseignement et de recherche français ou étrangers, des laboratoires publics ou privés. 


\title{
A $\mathrm{M}_{3}$ MUSCARINIC RECEPTOR COUPLED TO INOSITOL PHOSPHATE FORMATION IN THE RAT COCHLEA?
}

\author{
Janioue Guiramand, ${ }^{*}$ Ebrahim Mayat, Sylvain Bartolami, Marc Lenoir, \\ JEAN-François RumignY, $†$ RÉmy PUJOL and MAX RÉCASENS \\ INSERM-U. 254, Laboratoire de Neurobiologie de l'Audition, Hôpital St Charles, 34059 Montpellier \\ Cedex; and †Laboratoires de Recherche Delalande, 10 rue des Carrières, 92500 Rueil-Malmaison. \\ France
}

(Received 26 June 1989; accepted 2 January 1990)

\begin{abstract}
Various neuroactive substances, including excitatory and inhibitory amino acids, biogenic amines and neuropeptides, were tested for their ability to stimulate the inositol phosphate (IPs) cascade in the presence of lithium in the rat cochlea. Among them, only the muscarinic agonists (carbachol and oxotremorine $\mathbf{M}$ ) were able to stimulate the IPs formation in 12-day-old rat cochleas. The carbacholelicited IPs formation was inhibited by muscarinic antagonists with the following relative order of potency: atropine $>4$-DAMP $\gg$ pirenzepine $>$ methoctramine $=$ AF-DX 116. This pharmacological profile suggests that the activation of the $M_{3}$ muscarinic receptor subtype is responsible for the increase in IPs synthesis in the rat cochlea. However, an interaction with a $\mathrm{m} 5$ receptor subtype could not be completely excluded. The unusual link of only one receptor subtype with the phosphoinositide breakdown in the cochlea, as opposed to the usual existence of several receptors coupled to this transduction system in other organs such as the brain, suggest a unique role for muscarinic agonists in the cochlea.
\end{abstract}

The mammalian cochlea contains two types of hair cells: namely the inner hair cells (IHCs $\ddagger$ ) and the outer hair cells ( $\mathrm{OHCs})$. The auditory transmission between IHCs and the first auditory neurons (type I afferent neurons) is thought to be assumed by an excitatory amino acid, likely glutamate [1-4]. This transmission may be modulated by the efferent lateral olivocochlear fibers which synapse at the afferent dendrites of the type I auditory neurons. Several neurotransmitters including dopamine, GABA, acetylcholine have been identified in these fibers [5]. The OHCs receive neuronal information via the medial efferent system which is mainly cholinergic [6]. In addition, the OHCs contact the dendrites of type II neurones, which represent the other afferent system of the cochlea. This afferent system, for which the neurotransmitter remains unknown, represents only $5 \%$ of the whole cochlear afferent system.

The OHCs have been postulated to indirectly modulate IHCs activity $[7,8]$ probably due to their motile properties. Motility (shortening and elongation) of isolated OHCs has been shown to occur in response to intracellular current administration (fast motility) [9] or in response to neuroactive substances such as potassium or acetylcholine (slow motility) $[9,10]$. The molecular mechanisms, which underlie such OHCs motility, may originate from phosphoinositide metabolism and the subsequent intracellular calcium mobilization $[11,12]$, which in turn

\footnotetext{
* To whom correspondence should be addressed.
}

¥ Abbreviations: IHC, inner hair cell; OHC, outer hair cell; 4-DAMP, 4-diphenylacetoxy- $N$-methyl piperidine methiodide; AF-DX 116, 11-((2-((diethylamino)-methyl)1-piperidinyl)acetyl $-5,11$ - dihydro $-6 H$ - pyrido $(2,3-\mathrm{b})$ (1,4)-benzodiazepine-6 one. controls actin polymerization and the formation of microfilament assemblies [13].

Despite the importance of such molecular mechanisms in the understanding of cochlear functioning, no direct measurement of inositol phosphate formation has been performed in this organ. In the present paper, we examine the accumulation elicited by neuroactive substances of these second messenger molecules (inositol mono-, bis- and tris-phosphate) in the rat cochlea.

\section{MATERIALS AND METHODS}

Incorporation of $\left[{ }^{3} \mathrm{H}\right]$ inositol. Wistar rats of age 12 days were killed by decapitation. After dissecting out the bony capsule, whole cochleas were rapidly removed and immediately placed in Krebs-Ringer buffer, pH 7.4. The Krebs-Ringer buffer used contained $125 \mathrm{mM} \mathrm{NaCl} ; 3.5 \mathrm{mM} \mathrm{KCl} ; 1.25 \mathrm{mM}$ $\mathrm{KH}_{2} \mathrm{PO}_{4} ; 1.2 \mathrm{mM} \mathrm{MgSO}{ }_{4} ; 1.5 \mathrm{mM} \mathrm{CaCl} ; 10 \mathrm{mM}$ glucose and $25 \mathrm{mM} \mathrm{NaHCO}$. Before use, this buffer was equilibrated to $\mathrm{pH} 7.4$ by saturation with a gaseous mixture of $95 \% \mathrm{O}_{2}$ and $5 \% \mathrm{CO}_{2}(\mathrm{v} / \mathrm{v})$. Myo$\left[2-{ }^{3} \mathrm{H}\right]$ Inositol incorporation in 75 cochleas was carried out at $37^{\circ}$, under gassing of $95 \% \mathrm{O}_{2} / 5 \% \mathrm{CO}_{2}$, for $75 \mathrm{~min}$ in $5 \mathrm{~mL}$ Krebs-Ringer buffer containing $1 \mathrm{mM}$ cytidine and $50 \mu \mathrm{Ci}$ of the radioactive inositol (sp. act. $17 \mathrm{Ci} / \mathrm{mmol}$, CEA Saclay, France). The labelled cochleas were then washed four times in $5 \mathrm{~mL}$ Krebs-Ringer buffer before being individually distributed in plastic tubes containing $500 \mu \mathrm{L}$ KrebsRinger buffer. The tubes were then transferred to a water bath maintained at $37^{\circ}$ and continuously gassed with the gaseous mixture of $95 \% \quad \mathrm{O}_{2} / 5 \% \quad \mathrm{CO}_{2}$ throughout the subsequent experimental steps.

Agonist stimulation. $\mathrm{LiCl}(10 \mu \mathrm{L}$, final concentration $10 \mathrm{mM}$ ) and $20 \mu \mathrm{L}$ of an appropriate concentration of an antagonist (where applicable) were 
added to each tube. After $15 \mathrm{~min}$, the stimulatory neuroactive substance or buffer $(20 \mu \mathrm{L})$ was added. Following an additional $20 \mathrm{~min}$ of incubation, the reaction was stopped by the addition of $50 \mu \mathrm{L}$ perchloric acid (PCA 72\%) and, by placing the tubes on ice.

Measurement of $\left[{ }^{3} \mathrm{H}\right]$ inositol phosphates. The labelled IPs were purified and measured according to the method described by Bone $e t$ al. [14] modified as follows: the cochleas were homogenized using an Ultraturrax homogenizer. The homogenates containing the PCA-extracted $\left[{ }^{3} \mathrm{H}\right] \mathrm{IPs}$ were then centrifuged at $2000 \mathrm{~g}$ for $20 \mathrm{~min}$. The resulting supernatants were poured off and retained while the pellets were resuspended by homogenization in $1 \mathrm{~mL}$ PCA $(1 \%)$ and recentrifuged at $2000 \mathrm{~g}$ for $20 \mathrm{~min}$. The two PCA extracts were then pooled and neutralized with a $1.5 \mathrm{M} \mathrm{KOH} / 0.075 \mathrm{M}$ HEPES solution in the presence of universal indicator $\mathrm{pH} \mathrm{4-10.} \mathrm{The}$ resulting potassium perchlorate salt was then pelleted by centrifugation $(5 \mathrm{~min}$ at $2000 \mathrm{~g}$ ), resuspended in $2 \mathrm{~mL} 0.5 \mathrm{mM}$ EDTA $/ 5 \mathrm{mM} \mathrm{Na}_{2} \mathrm{~B}_{4} \mathrm{O}_{7}$ and washed by centrifugation $(5 \mathrm{~min}$ at $2000 \mathrm{~g}$ ). The supernatants from the two centrifugations were then pooled. A solution $(10 \mathrm{~mL})$ containing $0.5 \mathrm{mM}$ EDTA/5 mM Na $2 \mathrm{~B}_{4} \mathrm{O}_{7}$ was then added to the pooled supernatant. The extracts (containing $\left[{ }^{3} \mathrm{H}\right]$ inositol and $\left.\left[{ }^{3} \mathrm{H}\right] \mathrm{IPs}\right)$ thus obtained were then applied to Dowex anion-exchange columns (1X8 formate form; height of resin: $4 \mathrm{~cm}$; diameter: $0.8 \mathrm{~cm}$ ). Aliquots $(1.5 \mathrm{~mL})$ were taken from the flow-through fractions and subjected to liquid scintillation counting. Each column was then washed once with $20 \mathrm{~mL}$ water. Glycerophosphoinositides (GPI) were eluted with $20 \mathrm{~mL} 0.04 \mathrm{M}$ ammonium formate/ $/ 0.003 \mathrm{M}$ sodium tetraborate. The IPs were eluted with $15 \mathrm{~mL} 0.8 \mathrm{M}$ ammonium formate/0.1 M formic acid. For both the GPI and IPs fractions, 4-mL aliquots were taken and radioassayed. Columns were regenerated twice with $10 \mathrm{~mL} 2 \mathrm{M}$ ammonium formate $/ 0.1 \mathrm{M}$ formic acid and twice with $20 \mathrm{~mL}$ distilled water prior to re-use. Columns were discarded after five experiments. For liquid scintillation counting, $2.5 \mathrm{~mL}$ of Ready Gel scintillation fluid (Beckman Instruments Inc., Ireland) was added to the $1.5-\mathrm{mL}$ aliquots obtained from the flow-through fractions while 6 and $7 \mathrm{~mL}$ of Ready Gel were added to the 4-mL aliquots containing the eluted GPI and IPs, respectively.

Data calculation. Dose-response curves for agonists and antagonists were fitted using non-linear regression with experimental values weighted by the reciprocal of the variance, according to the logistic model described by De Lean et al. $[15,16]$. The computer programme used was the RS/ 1 release 3.0 program (BBN Software Product Corporation, Cambridge, MA, U.S.A.), run on a VAX 6210 microcomputer.

\section{RESULTS}

\section{Time course}

Carbachol (carb) enhanced IP $_{1}$ accumulation in the presence of $10 \mathrm{mM} \mathrm{Li}^{+}$at $37^{\circ}$ in the rat cochlea. This increase was exponential during the first $5 \mathrm{~min}$ and linear between 5 and $45 \mathrm{~min}$ of incubation (Fig. 1 upper panel). Carb did not induce any $\mathrm{IP}_{1}$ accumu-

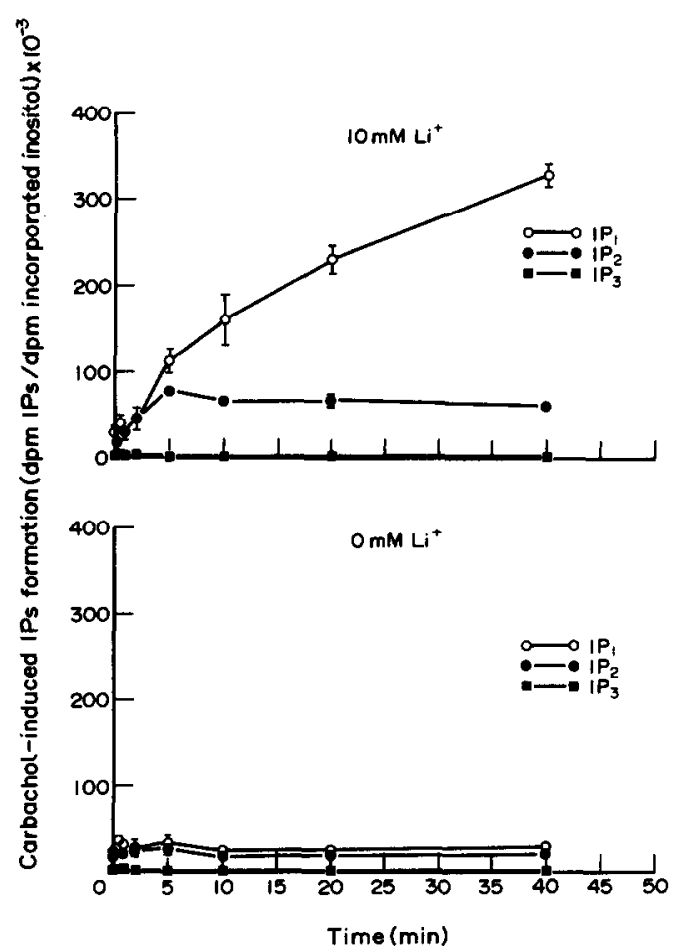

Fig. 1. Time course of carbachol-induced formation of $\left[{ }^{3} \mathrm{H}\right] I \mathrm{P}_{1},\left[{ }^{3} \mathrm{H}\right] I \mathrm{P}_{2}$ and $\left[{ }^{3} \mathrm{H}\right] \mathrm{IP}_{3}$ in rat cochleas. Experimental conditions are as described in Materials and Methods except that the cochleas were prelabelled with $500 \mu \mathrm{Ci}$ $\left[{ }^{3} \mathrm{H}\right]$ myo-inositol instead of $50 \mu \mathrm{Ci}$ for $75 \mathrm{~min}$, washed five times, and then stimulated for different time periods with $10 \mathrm{mM}$ carbachol in the absence or in the presence of $10 \mathrm{mM} \mathrm{LiCl}$. In addition, the reaction was stopped using $60 \mu \mathrm{L}$ of a solution containing PCA $(72 \%)$, EGTA $(1 \mathrm{mM})$ and a nonradioactive mixture of inositol phosphates $(2 \mathrm{mg}$ ) $\mathrm{mL}$ ) in order to inhibit the acidic phosphatases which catalyse the dephosphorylation of the various IPs metabolitcs. The clutions of the various metabolites from the Dowex 1 X8 columns were performed as follows: twice with $20 \mathrm{~mL}$ of water to remove $\left[{ }^{3} \mathrm{H}\right]$ myo-inositol, once with $15 \mathrm{~mL}$ of $0.04 \mathrm{M}$ ammonium formate/ $0.003 \mathrm{M}$ sodium tetraborate for GPI, twice with $15 \mathrm{~mL}$ of $0.15 \mathrm{M}$ ammonium formate $/ 0.005 \mathrm{M}$ sodium tetraborate for $\mathrm{IP}_{1}$, twice with $15 \mathrm{~mL}$ of $0.4 \mathrm{M}$ ammonium formate/0.1 M formic acid for $\mathrm{IP}_{2}$, twice with $15 \mathrm{~mL}$ of $0.8 \mathrm{M}$ ammonium formate/0.1 M formic acid for $\mathrm{IP}_{3}$ and once with $15 \mathrm{~mL}$ of $2 \mathrm{M}$ ammonium formate/0.1 M formic acid for the other inositol phosphates. Results are means $\pm S D$ of experiments done on at least six different cochleas (one IPs determination is performed for each individual cochlea). The basal $\mathrm{IP}_{1}, \mathrm{IP}_{2}$ and $\mathrm{IP}_{3}$ accumulation was not significantly affected by the presence of $10 \mathrm{mM} \mathrm{Li}^{+}$.

lation in the absence of $\mathrm{Li}^{+}$(Fig. 1 lower panel). Very little radioactivity was found in the $\mathrm{IP}_{2}$ and $\mathrm{IP}_{3}$ fractions and this was not affected by $\mathrm{Li}^{+}$. The basal levels of $\mathrm{IP}_{1}, \mathrm{IP}_{2}$ and $\mathrm{IP}_{3}$ did not change with $\mathrm{Li}^{+}$. The results were expressed as the ratios of $\mathrm{dpm}$ contained in the various IP fractions to the dpm of incorporated inositol. Similar patterns were obtained when results were expressed as dpm per mg of protein (data not shown). These preliminary experiments prompted us to measure the total IPs (containing about $98 \%$ of $\mathrm{IP}_{1}$ and $\mathrm{IP}_{2}$ ) for a $20 \mathrm{~min}$ 
Table 1. Effect of neuroactive substances on the IPs formation in the rat cochlea

\begin{tabular}{|c|c|c|}
\hline Agonist & $\begin{array}{c}\text { Maximum Concentration } \\
\text { Tested }(\mu \mathrm{M})\end{array}$ & $\begin{array}{l}\text { Effect on IPs } \\
\text { accumulation }\end{array}$ \\
\hline $\begin{array}{l}\text { Glutamate } \\
\text { Quisqualatc } \\
N \text {-Methyl-D-aspartate } \\
\text { Kainate }\end{array}$ & $\begin{array}{l}1000 \\
1000 \\
1000 \\
1000\end{array}$ & $\begin{array}{l}100 \pm 26 \\
118 \pm 16 \\
101 \pm 21 \\
124 \pm 52\end{array}$ \\
\hline $\begin{array}{l}\text { Nicotine } \\
\text { Carbachol } \\
\text { Oxtremorine } \mathbf{M}\end{array}$ & $\begin{array}{r}10,000 \\
10,000 \\
1000\end{array}$ & $\begin{aligned} 79 & \pm 29 \\
617 & \pm 66 \ddagger \\
727 & \pm 59 \ddagger\end{aligned}$ \\
\hline $\begin{array}{l}\text { Gamma-amino-butyric acid } \\
\text { Glycine }\end{array}$ & $\begin{array}{l}1000 \\
1000\end{array}$ & $\begin{aligned} 102 & \pm 23 \\
89 & \pm 8\end{aligned}$ \\
\hline $\begin{array}{l}\text { Noradrenaline } \\
\text { 5-Hydroxytryptamine } \\
\text { Dopamine }\end{array}$ & $\begin{array}{l}1000 \\
1000 \\
1000\end{array}$ & $\begin{array}{l}114 \pm 24 \\
135 \pm 23 \\
126 \pm 12\end{array}$ \\
\hline $\begin{array}{l}\text { Substance P } \\
\text { Neuropeptide Y } \\
\text { Calcitonin gene related peptide } \\
\text { Vasoactive intestinal peptide } \\
\text { Arginine-vasopressin } \\
\text { Cholecystokinin } \\
\text { Met-enkephalin } \\
\text { Leu-enkephalin } \\
\text { Met-enkephalin-Arg6-Phe }{ }^{7} \\
\text { Oxytocin } \\
\text { DAGO\$ } \\
\text { DTLET\| } \\
\text { DPLPE }\end{array}$ & $\begin{array}{l}1 \\
1 \\
1 \\
1 \\
1 \\
1 \\
1 \\
1 \\
1 \\
1 \\
1 \\
1 \\
1\end{array}$ & $\begin{aligned} 113 & \pm 26 \\
86 & \pm 17 \\
96 & \pm 13 \\
109 & \pm 17 \\
87 & \pm 12 \\
81 & \pm 10 \\
115 & \pm 29 \\
100 & \pm 18 \\
109 & \pm 12 \\
99 & \pm 17 \\
82 & \pm 11 \\
72 & \pm 3 \dagger \\
91 & \pm 34\end{aligned}$ \\
\hline $\begin{array}{l}\text { Potassium } \\
\text { A } 23187 \\
\text { Monensin } \\
\text { Valinomycin K } \\
\text { Veratridine }\end{array}$ & $\begin{array}{r}60,000 \\
5 \\
50 \\
1 \\
10\end{array}$ & $\begin{aligned} 92 & \pm 13 \\
96 & \pm 23 \\
145 & \pm 37 \\
79 & \pm 12 \\
92 & \pm 23\end{aligned}$ \\
\hline
\end{tabular}

* Results are expressed as percentages of control values. The mean control value is $\left.(47 \pm 13) \times 10^{3} \mathrm{dpm} \mathrm{IPs/dpm} \mathrm{[}{ }^{3} \mathrm{H}\right]$ inositol incorporated and the mean value of $\left[{ }^{3} \mathrm{H}\right]$ inositol incorporation is $41,130 \pm 12,170 \mathrm{dpm}$ per cochlea. Results are expressed as means \pm SD of at least six individual determinations. The statistical significance of the agonist-stimulated IPs formation versus the control IPs values was calculated by two-tailed Student's $t$-test. $(\dagger \mathrm{P}<0.01 ; \ddagger \mathrm{P}<0.001)$.

$\S$ DAGO: (D-ala ${ }^{2}, N$ methyl-phe ${ }^{4}$, glyol $\left.^{5}\right)$ enkephalin.

|| DTLET: (D-thr' ${ }^{2}$, thr $^{6}$ ) leu-enkephalin.

I DPLPE: (D-pen ${ }^{2}$, L-pen ${ }^{5}$ ) enkephalin.

incubation period and to express the results as ratios (dpm IPs/dpm incorporated $\left[{ }^{3} \mathrm{H}\right]$ myo-inositol) for the following experiments.

\section{Effects of neuroactive substances on the IPs formation in the rat cochlea}

A large number of neuroactive substances, some of which are known to be present in the cochlea [5], ions and ionophores were screened for their ability to stimulate IPs formation in the cochlea (see Table 1 ). With the exception of the muscarinic agonists carbachol and oxotremorine $M$, none of the substances tested (nicotine included) had any significant stimulatory effect.

\section{Dose-response curve}

Carbachol and oxotremorine $\mathbf{M}$ induced IPs accumulation in a dose-dependent manner (Fig. 2). From the dose-response relationships, the $\mathrm{EC}_{50}$ values were calculated, using a curve fitting programme indicated in Materials and Methods. They were $28 \pm 20 \mu \mathrm{M}$ and $87 \pm 19 \mu \mathrm{M}$ for oxotremorine $M$ and carbachol, respectively. A pre-analysis according to the logistic model proposed by Black et al. [17] shows that for the two agonists the slopes are approximately equal to 1 . The $E_{\max }$ values for carbachol and for oxotremorine $M$ are significantly different. These values expressed as percentages of the basal values are $570 \pm 60 \%$ and $799 \pm 93 \%$, respectively.

\section{Effect of cholinergic antagonists on carbachol-elicited IPs accumulation}

A broad range of cholinergic receptor antagonists were assessed for their ability to block the increased accumulation evoked by carbachol. The nicotinic antagonists D-tubocurarine and $\alpha$-bungarotoxin had no effect. On the contrary, muscarinic antagonists inhibited all the IPs formation induced by $10^{-3} \mathrm{M}$ carbachol (Fig. 3). None of these cholinergic antagonists affected the basal IPs accumulation, except for a high concentration of methoctramine. At 


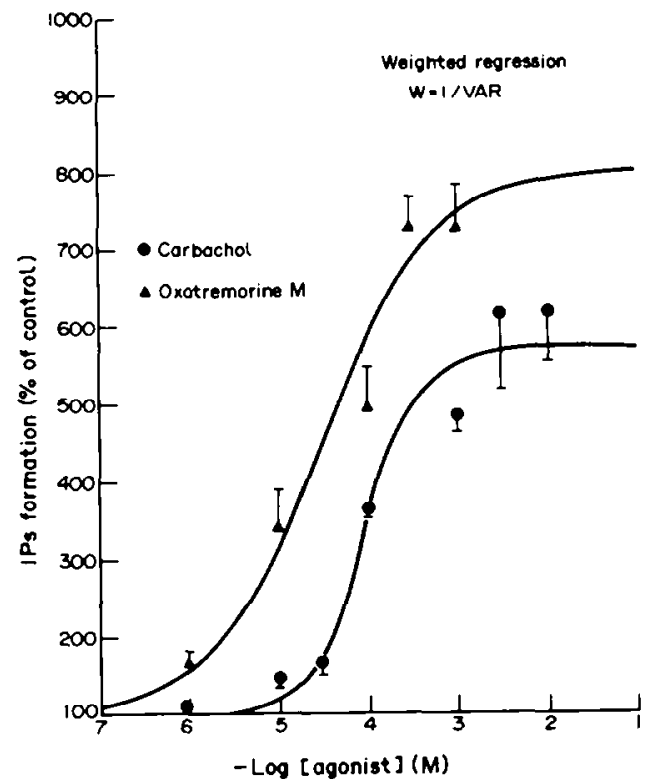

Fig. 2. Concentration-response relationships of carbacholand oxotremorine M-induced IPs formation in the rat cochlea. Cochleas were labelled for $75 \mathrm{~min}$ with $50 \mu \mathrm{Ci}\left[{ }^{3} \mathrm{H}\right]$ myoinositol, and then washed four times to remove the excess of radioactive inositol. After preincubation with $10 \mathrm{mM}$ $\mathrm{LiCl}$ at $37^{\circ}$ for $15 \mathrm{~min}$, increasing concentrations of carbachol or oxotremorine $M$ were added and the cochleas were further incubated for $20 \mathrm{~min}$. The accumulation of $\left[{ }^{3} \mathrm{H}\right] \mathrm{IPs}$ was measured by scintillation counting following Dowex $1 \times 8$ column chromatography. Results which are means $\pm \mathrm{SE}$ of experiments done on at least five different cochleas, show stimulation as a percentage of the basal IPs formation. Basal IPs formation was $54,180 \pm 4913 \mathrm{dpm} / \mathrm{mg}$ protein (mean $\pm \mathrm{SE}$ ).

$10^{-3} \mathrm{M}$, methoctramine alone stimulates IPs accumulation (about $400 \%$ of basal value). The same level of stimulation is also obtained in the co-presence of $10^{-3} \mathrm{M}$ carbachol. The relative order of potency of the muscarinic antagonists were atropine $>4$-DAMP $>$ pirenzepine $>$ methoctramine $=$ AF-DX 116. The ${ }^{I} C_{50}$ values which were calculated from the inhibition curves and were $0.007 \pm 0.007,0.030 \pm 0.008$, $2.0 \pm 0.8,33 \pm 7$ and $63 \pm 42 \mu \mathrm{M}$ for atropine, 4 DAMP, pirenzepine, AF-DX 116 and methoctramine respectively. For each antagonist, pseudoHill numbers were determined (Table 2). In all cases they are not significantly different from 1 . However, for methoctramine, this number is relatively low.

\section{DISCUSSION}

Our results indicate that among the neuroactive substances tested (Table 1), some of which are known to occur in the cochlea [5], only cholinergic agonists are able to stimulate the accumulation of IPs in the cochlea. Although nicotinic receptors seem to occur in the cochlea, (nicotine potentiates the submaximal effects of the stimulation of the crossed olivocochlear bundle [18]) their activation did not lead to IPs stimulation. Conversely, cholinergic

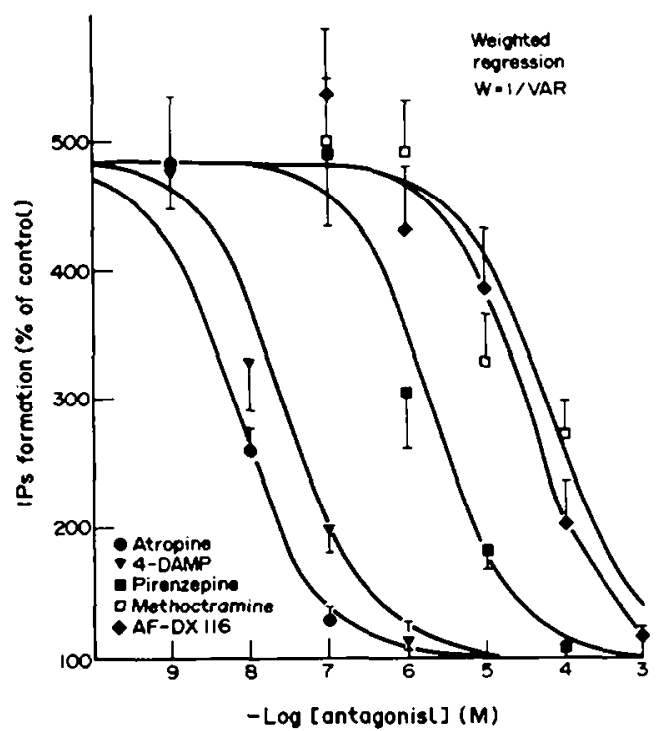

Fig. 3. Effects of muscarinic antagonists on carbacholinduced IPs formation in the cochlea. Experimental conditions are as described in Materials and Methods. Cholinergic antagonists $\left(10^{-7} \mathrm{M}-10^{-3} \mathrm{M}\right)$ were tested for their ability to inhibit IPs formation induced by $1 \mathrm{mM}$ carbachol. Results which are means \pm SE of experiments done on at least six different cochleas, show stimulation as a percentage of the basal IPs formation. Antagonists per se (atropine, 4-DAMP, methoctramine, pirenzepine and AFDX 116) did not affect the basal IPs formation at the concentrations tested (except for high concentrations of methoctramine greater than $10^{-4} \mathrm{M}$ ). D-Tubocurarine and $\alpha$-bungarotoxin were without effect both on the basal and carbachol-stimulated IPs accumulation.

Table 2. Calculated $\mathrm{IC}_{50}$ and pseudo-Hill values for cholinergic antagonists for inhibition of $1 \mathrm{mM}$ carbacholinduced IPs formation in the rat cochlea

\begin{tabular}{lcc}
\hline \multicolumn{1}{c}{ Antagonist } & $\mathrm{IC}_{S \mathrm{~S}}(\mu \mathrm{M})$ & $n_{\mathrm{H}}$ \\
\hline Atropine & $0.007 \pm 0.007$ & $0.83 \pm 0.47$ \\
4-DAMP & $0.03 \pm 0.008$ & $0.94 \pm 0.15$ \\
Pirenzepine & $2.0 \pm 0.8$ & $0.90 \pm 0.17$ \\
AF-DX 116 & $33 \pm 7$ & $0.91 \pm 0.15$ \\
Methoctramine & $63+42$ & $0.79 \pm 0.49$ \\
\hline
\end{tabular}

These values were calculated from the results presented in Fig. 3 as described in Materials and Methods. They are expressed as means $\pm \mathrm{SE}$ of at least six individual determinations.

agonists of the muscarinic receptor subtype (carbachol and oxotremorine $M$ ) increase the metabolism of IPs with a high apparent affinity. The fact that the $E_{\max }$ values calculated for these two agonists are significantly different may indicate that carbachol is a partial agonist. The carbachol-stimulated IPs formation is not blocked by nicotinic antagonists such as D-tubocurarine and $\alpha$-bungarotoxin while it is inhibited by muscarinic antagonists (atropine, pirenzepine, 4-DAMP, methoctramine and AF-DX 116). This clearly demonstrates that a muscarinic 
receptor is responsible for the IPs formation in the cochlea. Muscarinic receptors have recently been divided into five subtypes, ${ }^{*}$ named $\mathrm{m} 1, \mathrm{~m} 2, \mathrm{~m} 3, \mathrm{~m} 4$ and $\mathrm{m} 5$ on the basis of molecular cloning experiments and the expression of this cloned muscarinic receptor in various cells [19-21]. The $\mathrm{m} 1$ and $\mathrm{m} 2$ receptor subtypes have also been cloned from porcine brain and heart [22-24]. In order to determine which muscarinic receptor is implicated in the cholinergicinduced IPs formation in the cochlea, we have measured the inhibition, by various muscarinic antagonist of the IPs accumulation, induced by $1 \mathrm{mM}$ carbachol. Although it would be better to determine $K_{i}$ values from Schild plot analyses, we have only measured the $\mathrm{IC}_{50}$ value for each antagonist in this paper (Table 2). The reasons for this are technical limitations such as the time taken for dissection, the time-restricted period for cochlear viability and the very small quantities of biological tissue present per cochlea. However, since the same concentration of carbachol was used for studying the antagonist inhibition, $\mathrm{IC}_{50}$ values thus determined will provide an approximate rank order of potency of the antagonists. Subsequently, the subtype of receptor involved can be determined. The most widely used classification of muscarinic receptor subtypes was based on the relative affinities of the antagonists, pirenzepine and AF-DX 116 in particular [25-27]. $\mathrm{M}_{1}$ receptors express a high apparent affinity toward pirenzepine and an intermediate affinity toward AFDX $116[26,28]$, whereas $M_{2}$ receptors "cardiac type" $\left(\mathrm{M}_{2 \mathrm{alpha}}\right)$ possess a low apparent affinity for pirenzepine and a high affinity for AF-DX 116 [2628]. $M_{3}$ receptors, previously known as the $M_{2}$ "glandular type" $\left(\mathrm{M}_{2 \text { beta }}\right)$ present a low apparent affinity toward both pirenzepine and AF-DX 116 and a high affinity toward 4-DAMP [28, 29]. Methoctramine was found to be as effective and selective as AF-DX 116 for the $M_{2}$ receptor [30, 31]. No specific antagonists, yet tested, allowed the distinction of $\mathrm{m} 4$ or $\mathrm{m} 5$ from the rest of the muscarinic receptor subtypes [32]. By using a large variety of antagonists, it is possible to approximate the identification of the specific subtype of muscarinic receptor involved as demonstrated by a recent displacement-binding study carried out in CHO-K1 cells, in which cloned muscarinic receptors were expressed [32]. However, the pharmacological profile determined in this study cannot be easily applied to muscarinic receptor subtype identification in other experimental models. Indeed, artificial receptor gene expression does not necessarily simulate exactly the expression occurring in vivo. Another indirect manner of characterization of receptor subtypes is the study of the biochemical

\footnotetext{
* The nomenclature of the muscarinic receptor subtypes used in this paper is that recommended recently in the supplement of Trends in Pharmacological Sciences, December 1989 , p. VII by the nomenclature committee of the fourth symposium on muscarinic subtypes. According to this nomenclature, the pharmacologically characterized receptor subtypes are known as $\mathbf{M}_{1}, \mathbf{M}_{2}$ and $\mathbf{M}_{3}$, while those characterized by molecular cloning techniques are named $\mathrm{m} 1, \mathrm{~m} 2, \mathrm{~m} 3, \mathrm{~m} 4$ and $\mathrm{m} 5$. It is likely that the $\mathrm{m} 1$ sequence corresponds to that of the $M_{1}$ receptor, $m 2$ to the $M_{2}$ receptor and $m 3$ to the $M_{3}$ receptor.
}

responses triggered by their activation. Muscarinic receptors are coupled to a variety of second messenger systems involving adenylate cyclase and phosphatidylinositol metabolism as well as to ion channels [20, 33-41]. In fact, it was reported that $\mathbf{M}_{1}(\mathrm{~m} 1)$, $M_{3}(\mathrm{~m} 3)$ and $\mathrm{m} 5$ receptors are coupled with the stimulation of phosphoinositides hydrolysis $[20,26,29,35-37,39,40]$ whereas $\mathrm{m} 2$ and $\mathrm{m} 4$ are mainly linked to the inhibition of adenylate cyclase $[36,38]$.

Our pharmacological results indicate that the muscarinic receptor subtypes involved in the IPs formation in the rat cochlea is probably a $\mathrm{M}_{3}$ receptor. In fact, pirenzepine has a low apparent affinity $\left(\mathrm{IC}_{50}=2 \times 10^{-6} \mathrm{M}\right)$ in inhibiting IPs synthesis which rules out the possibility of an interaction with the $M_{1}$ receptor. A similar low apparent affinity of pirenzepine was recently reported in receptor-binding studies to cochlear membranes using $\left[{ }^{3} \mathrm{H}\right]-1$-quinuclidinylbenzylate [42]. We found a relatively low efficacy of AF-DX 116 or methoctramine for inhibiting the carbachol-induced IPs accumulation in the rat cochlea ( $\mathrm{IC}_{50}=33$ and $63 \mu \mathrm{M}$, respectively). This excludes the involvement of a $\mathrm{M}_{2}$ receptor subtype in this IPs response since these two antagonists present a high affinity for the $\mathrm{M}_{2}$ receptor subtype [26-30]. The antagonist 4-DAMP inhibits the carbachol-induced IPs response with a high apparent affinity, thus suggesting an action via the $\mathrm{M}_{3}$ receptor [29]. However, the potency of 4-DAMP has not been tested for its inhibitory action neither on the binding of muscarinic ligands to $\mathrm{m} 4$ or $\mathrm{m} 5$ receptor subtypes nor on the biochemical responses associated with the activation of these two latter receptor subtypes. Nevertheless, $\mathrm{m} 4$ receptors are rather shown to be coupled to adenylate cyclase inhibition than to IPs formation [36], suggesting that the response observed here, is probably not mediated by a $\mathrm{m} 4$ muscarinic receptor. On the other hand, the expression of $\mathrm{m} 5$ receptors has not yet been observed in any tissue or cell line [32]. The paucity of pharmacological data concerning this receptor subtype, does not allow us to rule out the possibility of the existence of a m5 muscarinic receptor linked to inositol phosphate formation in the cochlea. If this is so, this will be the first indication of the natural expression of the $\mathrm{m} 5$ receptor gene in an organ. In fact, the antagonists used present about the same rank order of potencies in the binding studies on both the $\mathrm{m} 3$ and $\mathrm{m} 5$ receptors expressed in CHO$\mathrm{K} 1$ cells: atropine $>$ methoctramine $>$ pirenzepine $\gg$ AF-DX 116 [32]. In our experiments, we found the following order of inhibitory action on carbacholstimulated IPs formation: atropine $\gg$ pirenzepine $\gg$ AF-DX $116=$ methoctramine. The apparent discrepancy concerning the inhibitory effect of methoctramine between the two sets of results may originate from the fact that methoctramine at concentrations greater than $10^{-4} \mathrm{M}$ becomes an agonist in the cochlea. This finding, which has also been reported in the rat cerebral cortex [43], may explain why the Hill number for methoctramine is not equal to 1 . A low Hill number for methoctramine has also been obtained in $\left[{ }^{3} \mathrm{H}\right]-N$-methylscopolamine displacement experiments on rat submaxillary gland membranes, thought to possess only $M_{3}$ receptors [32]. Taken 
together our results seem to indicate that cholinergicinduced IPs formation in the cochlea is probably mediated by the activation of a $\mathbf{M}_{3}$ muscarinic receptor.

Our results also show that neither glutamate nor quisqualate stimulate IPs formation in the rat cochlea. Nevertheless several reports have shown that an excitatory amino acid is probably involved in the transmission between the IHCs and the primary auditory neurons [44] by activating a quisqualate receptor $[1,45]$. If so, the quisqualate receptor involved did not correspond to that linked to the phosphoinositide metabolism [46]. These facts reinforce the conclusion of our previous work [46] which indicate that two subtypes of quisqualate receptors do indeed exist in the central nervous system, one linked to ion channels, the other one to phosphoinositides metabolism.

In conclusion, our data strongly suggest that among the known neuroactive substances found in the rat cochlea only muscarinic agonists mediate the stimulation of IPs turnover likely via a $\mathrm{M}_{3}$ receptor subtype. Acetylcholine is thought to be the main neurotransmitter between the medial efferent system and the OHCs [6], and inositol triphosphate causes the contraction of permeabilized OHCs in vitro $[11,12]$. Thus, the activation of this second messenger pathway in the cochlea by acetylcholine via a $\mathbf{M}_{3}$ receptor may play a key role in the triggering or the control of slow OHCs motility, although the accurate cellular location of this second messenger remains to be elucidated.

Acknowledgements-We thank Dr C. Melchiorre (University of Bologna, Italy) for kindly providing us with the methoctramine and the Laboratoires Boehringer Ingelheim, Reims, France for the gift of AF-DX 116. We are also grateful to Dr M. Eybalin for helpful discussion, M. Gallego for technical assistance and A. Bara for typing this manuscript. The work was supported by grants from M.R.E.S., C.N.A.M.T.S.-INSERM, IPSEN, Air Liquide and the Institut $\mathrm{H}$. Beaufour (Paris).

\section{REFERENCES}

1. Jenison GL and Bobbin RP, Quisqualate excites spiral ganglion neurons of the guinea pig. Hearing Res 20: 261-265, 1985.

2. Bobbin RP, Glutamate and aspartate mimic the afferent transmitter in the cochlea. Exp Brain Res 34: 389 393, 1979.

3. Eybalin $M$ and Pujol R, A radioautographic study of the $\left[{ }^{3} \mathbf{H}\right]$-L-glutamate and $\left[{ }^{3} \mathbf{H}\right]$-L-glutamine uptake in the guinea-pig cochlea. Neuroscience 9: 863-871, 1983.

4. Klinke R and Oertel W, Amino acids-putative afferent transmitter in the cochlea? Exp Brain Res 30: 145 $148,1977$.

5. Eybalin $M$ and Pujol $R$, Cochlear neuroactive substances. Arch Oto-Rhino-Laryngol 246: 228-234, 1989.

6. Eybalin $M$ and Pujol $R$, Choline acetyltransferase (ChAT) immunoelectron microscopy distinguishes at least three types of efferent synapses in the organ of Corti. Exp Brain Res 65: 261-270, 1987.

7. Mountain DC, Changes of endolymphatic potential and crossed olivocochlear bundle stimulation alter cochlear mechanics. Science 210: 71-72, 1980.

8. Siegel JH and Kim DO, Efferent control of cochlear mechanics? Olivocochlear bundle stimulation affects cochlear biomechanical nonlinearity. Hearing Res 6: 171-182, 1982.

9. Brownell WE, Bader CR, Bertrand D and de Ribaupierre $\mathrm{Y}$, Evoked mechanical responses of isolated cochlear outer hair cells. Science 227: 194-196, 1985.

10. Slepecky N, Ulfendahl $M$ and Flock $A$, Shortening and elongation of isolated outer hair cells in response to application of potassium gluconate, acetylcholine and cationized ferritin. Hearing Res 34: 119-126, 1988.

11. Schacht $J$ and Zenner $H$, The phosphoinositide cascade in isolated outer hair cells: possible role as second messenger for motile responses. Hearing Res 22: 94, 1986.

12. Schacht $J$ and Zenner $H$, Evidence that phosphoinositides mediate motility in cochlear outer hair cells. Hearing Res 31: 155-160, 1987.

13. Lassing I and Lindberg U, Evidence that the phosphatidylinositol cycle is linked to cell motility. Exp Cell Res 174: 1-15, 1988.

14. Bone EA, Fretten P, Palmer S, Kirk CJ and Michell RH, Rapid accumulation of inositol phosphates in isolated rat superior cervical sympathetic ganglia exposed to $V_{1}$-vasopressin and muscarinic cholinergic stimuli. Biochem J 221: 803-811, 1984.

15. De Lean A, Munson PJ and Rodbard D, Simultaneous analysis of families of sigmoidal curves. Am J Physiol 235: E97-E102, 1978.

16. De Lean A, Hancock AA and Lefkowitz RJ, Validation and statistical analysis of a computer modeling method for quantitative analysis of radioligand binding data for mixtures of pharmacological receptor subtypes. Mol Pharmacol 21: 5-16, 1982.

17. Black JW, Leff P, Shankley NP and Wood J, An operational model of pharmacological agonism: the effect of $E /[A]$ curve shape on agonist dissociation constant estimation. BrJ Pharmacol 84: 561-571, 1985.

18. Klinke R, Neurotransmission in the inner ear. Hearing Res 22: 235-244, 1986.

19. Bonner TI, Buckley NJ, Young AC and Brann MR, Identification of a family of muscarinic acetylcholine receptor genes. Science 237: 527-532, 1987.

20. Bonner TI, Young AC, Brann MR and Buckley NJ, Cloning and expression of the human and rat $\mathrm{m} 5 \mathrm{musca}$ rinic acetylcholine receptor genes. Neuron 1: 403-410, 1988.

21. Peralta EG, Ashkenazi A, Winslow JW, Smith DH, Ramachandran J and Capon DJ, Distinct primary structure, ligand-binding properties and tissue-specific expression of four human muscarinic acetylcholine receptors. EMBO J 6: 3923-3929, 1987.

22. Braun T, Schofield PR, Shivers BD, Pritchett DB and Seeburg PH, A novel subtype of muscarinic receptor identified by homology screening. Biochem Biophys Res Commun 149: 125-132, 1987.

23. Kubo T, Fukada K, Mikami A, Maeda A, Takahashi H, Mishima M, Haga $T$, Haga K, Ichiyama A, Kangawa $\mathrm{K}$, Kojima $\mathbf{M}$, Matsuo $\mathrm{H}$, Hirose $\mathrm{T}$ and Numa $\mathrm{S}$, Cloning, sequencing and expression of complementary DNA encoding the muscarinic acetylcholine receptor. Nature 323: 411-416, 1986.

24. Peralta EG, Winslow JW, Peterson GL, Smith DH, Ashkenazi A, Ramachandran J, Schimerlik MI and Capon DJ, Primary structure and biochemical properties of an M2 muscarinic receptor. Science 236: 600$605,1987$.

25. Hammer R, Berrie CP, Birdsall NJM, Burgen ASV and Hulme EC, Pirenzepine distinguishes between different subclasses of muscarinic receptors. Nature 283: 90-92, 1980.

26. Ladinsky H, Giraldo E, Monferini E, Schiavi GB, Vigano MA, De Conti L, Micheletti $R$ and Hammer R, Muscarinic receptor heterogeneity in smooth muscle: 
binding and functional studies with AF-DX 116. Trends Pharmacol Sci Suppl February: 44-48, 1988.

27. Barnes PJ, Minette $P$ and Maclagan J, Muscarinic receptor subtypes in airways. Trends Pharmacol Sci 9: 412-416, 1988 .

28. Micheletti R, Montagna E and Giachetti A, AF-DX 116 , a cardioselective muscarinic antagonist. $J$ Pharmacol Exp Ther 241: 628-634, 1987.

29. Doods HN, Mathy M-J, Davidesko D, van Charldorp $\mathrm{KJ}$, de Jonge $A$ and van Zwieten PA, Selectivity of muscarinic antagonists in radioligand and in vivo experiments for the putative $\mathbf{M}_{1}, \mathbf{M}_{2}$ and $\mathbf{M}_{3}$ receptors. $J$ Pharmacol Exp Ther 242: 257-262, 1987.

30. Melchiorre $C$, Angeli $P$, Lambrecht $G$, Mutschler E, Picchio MT and Wess J, Antimuscarinic action of methoctramine, a new cardioselective M-2 muscarinic receptor antagonist, alone and in combination with atropine and gallamine. Eur J Pharmacol 144: 117-124, 1987.

31. Melchiorre C, Minarini A, Angeli P, Giardina D, Gulini U and Quaglia W, Polymethylene tetramines as muscarinic receptor probes. Trends Pharmacol Sci Suppl December: 55-59, 1989.

32. Buckley NJ, Bonner TI, Buckley CM and Brann MR, Antagonist binding properties of five cloned muscarinic receptors expressed in CHO-K1 cells. Mol Pharmacol 35: 469-476, 1989.

33. Neer EJ and Clapham DE, Role of $G$ protein subunits in transmembrane signalling. Nature 333: 129-134, 1988.

34. Berridge MJ and Irvine RF, Inositol trisphosphate, a novel second messenger in cellular signal transduction. Nature 312: 315-321, 1984.

35. Lazareno S, Kendall DA and Nahorski SR, Pirenzepine indicates heterogenicity of muscarinic receptors linked to cerebral inositol phospholipid metabolism. Neuropharmacology 24: 593-595, 1985.

36. Peralta EG, Ashkenazi A, Winslow JW, Ramachandran J and Capon DJ, Differential regulation of PI hydrolysis and adenylyl cyclase by muscarinic receptor subtypes. Nature 334: 434-437, 1988.
37. Lai J, Mei L, Roeske WR, Chung F-Z, Yamamura $\mathrm{HI}$ and Venter JC, The cloned murine $\mathrm{M}_{1}$ muscarinic receptor is associated with the hydrolysis of phosphatidylinositols in transfected murine B82 cells. Life Sci 42: 2489-2502, 1988.

38. Ashkenazi A, Winlow JW, Peralta EG, Peterson GL, Schimerlik MI, Capon DJ and Ramachandran J, A $\mathbf{M}_{2}$ muscarinic receptor subtype coupled to both adenylyl cyclase and phosphoinositide turnover. Science 238: 672-675, 1987.

39. Marty A, Control of ionic currents and fluid secretion by muscarinic agonists in exocrine glands. Trends Neurosci 10: 373-377, 1987.

40. Fukuda K, Higashida H, Kubo T, Maeda A, Akiba I, Buko $H$, Mishina $M$ and Numa $S$, Selective coupling with $\mathrm{K}^{+}$-currents of muscarinic acetylcholine receptor subtypes in NG 108-15 cells. Nature 335: 355-358, 1988.

41. Jones SVP, Barker JL, Bonner TI, Buckley NJ and Brann MR, Electrophysiological characterization of cloned M1 muscarinic receptors expressed in A9 L cells. Proc Natl Acad Sci USA 85: 4056-4060, 1988.

42. Van Megen YJB, Klaassen ABM, Rodrigues de Miranda JF and Kuijpers W, Cholinergic muscarinic receptors in rat cochlea. Brain Res 474: 185-188, 1988.

43. Lee NH, Forray $\mathrm{C}$ and El-Fakahany EE, Methoctramine, a cardioselective muscarinic antagonist, stimulates phosphoinositide hydrolysis in rat cerebral cortex. Eur J Pharmacol 167: 295-298, 1989.

44. Jenison GL, Winbery $S$ and Bobbin RP, Comparative actions of quisqualate and $N$-methyl-D-aspartate, excitatory amino acid agonists, on guinea-pig cochlear potentials. Comp Biochem Physiol 84C: 385-389, 1986.

45. Littman T, Bobbin RP, Fallon M and Puel J-L, The quinoxalinediones DNQX, CNQX and two related congeners suppress hair cell-to-auditory nerve transmission. Hearing Res 40: 45-54, 1989.

46. Recasens M, Guiramand J, Nourigat A, Sassetti I and Devilliers $G, A$ new quisqualate receptor subtype (sAA $\mathrm{A}_{2}$ ) responsible for the glutamate-induced inositol phosphate formation in rat brain synaptoneurosomes. Neurochem Int 13: 463-467, 1988. 